\title{
Identity in the Gig Economy: Affect and Agency
}

\author{
Joy H. Karriker \\ East Carolina University \\ Nathan S. Hartman \\ Illinois State University \\ Flavia Cavazotte \\ Pontifícia Universidade Católica do Rio de Janeiro \\ W. Lee Grubb, III \\ East Carolina University
}

\begin{abstract}
We highlight the importance of individual work identity as organizational identification's counterpart in the new world of work and propose a theoretical model regarding the influences of affective events and worker agency on gig worker identity construction. We suggest individual work identity perceptions can be generated by negotiated exchanges with organizations, groups, and networks that may serve as organizational proxies. Drawing on Affective Events Theory and Sense of Agency, we assert that the physical, temporal, and administrative connections with an organization interact with work configuration to influence the affective reactions that impact individual work identities in the gig economy context.
\end{abstract}

Keywords: organizational identity, work identity, gig economy, affective events theory, sense of agency

\section{INTRODUCTION}

How an employee thinks and feels about an organization, and his or her place in it, has long been attractive to scholars and practitioners, particularly to the extent that these thoughts and feelings affect employees' work behaviors. Traditionally, the environment of an organization makes possible human interactions that affect an individual's relationships with other employees and with the organization itself, and the organization serves as a referent in an individual's organizational identity development. Alternative forms of work have become more prevalent in recent years and continue to grow as organizations in general, and particularly corporations, seek a leaner and more agile profile in the gig economy (Ashford, Caza, \& Reid, 2018). Companies with locations in six or more countries plan to increase their utilization of contingent workers by $24 \%$ by 2021 , and the global economy will be "dominated" by gig work (Banks, 2019). As global gig economy spending nears five trillion USD annually, the changing ecosystem of the workforce (Agarwal, Bersin, Lahiri, Schwartz, \& Volini, 2018) highlights the need for the study of other relevant contextual factors and vehicles for supporting the construction of an individual's work identity. 
We note the lack of rich theoretical and practical understanding of the implications of work configurations facilitated by the gig economy on an individual's work identity and seek to contribute to this scholarship.

Tajfel's (1978) definition of social identity, "that part of an individual's self-concept which derives from his knowledge of his membership of a social group or groups together with the value and emotional significance attached to that membership" (p.63) provides a foundation for this research. To the extent that one's own affiliation with an organization is salient, one may 'identify' with an organization in a social identity process resulting in one's organizational identification (OID) (He \& Brown, 2013). That is, social identity theory (SIT) supports the idea that an individual experiences organizational identification as a specific self-concept, part of an individual's identity. Ultimately, this organizational identification affects work-related behaviors, interpersonal relationships with colleagues and, eventually, the performance of the organization as a whole. However, increasingly dynamic work settings where workers experience less structured relationships with, within, and without work organizations, lead workers to configure their own work identities as needed (Petriglieri, Ashford, \& Wrzesniewski, 2019; Barley, Bechky, \& Milliken 2017). Not all workers have a single, focal employing organization with which to identify, thus precipitating their need of a different identification process. Such ad hoc work identity construction contributes to workers' self-esteem and insulates them against social anxiety (Ashforth, Harrison, \& Corley, 2008; Petriglieri et al., 2019), but their process(es) will be quite different from those of traditional workers, whom we define as employed by a single organization. We refer to workers who have a single permanent employer with whom they craft an organizational identity are viewed as conventional or traditional workers; yet other categories of workers typically have been lumped into a single category of nonstandard work (Cappelli \& Keller, 2014). Recently, independent, or gig, workers have become a subcategory in the broad nonstandard work classification and shattered the stereotype that 'nonstandard' also means low wages, undesirable work, or bad jobs to become a type of work arrangement that can be desirable without the structure found in conventional work arrangements. We deduce that a central and structured referent organization is absent for gig workers; for them, work identities serve similar psychological need fulfillment purposes as does traditional workers' organizational identification. That is, although extant literature informs the development of an individual's social identity (i.e., organizational identification) in traditional, singleemployer work settings, there is less known about how one develops a work identity absent the central structure provided by an organization. Here, we assert that the social identity literature should now attend to the increasingly prevalent category of gig workers. We focus on the development of work identities for those who experience gig work configurations and an examination of the processes that are pivotal in work identity development. Additionally, drawing on Affective Events Theory (AET), we propose potential mechanisms that shape positive or negative work identity development among gig workers. The framework extends and bridges knowledge in the literature on identity work by presenting testable propositions for the role of new employment configurations in that process and the specific factors that shape their impact.

\section{SOCIAL IDENTITY THEORY}

Tajfel's social identity theory (1978) holds that one's knowledge of her membership in a social group, or groups, serves as the basis for a portion of her self-concept. Ashforth (2001) suggests that this identity has dimensions - cognitive and affective - and that identity-related behaviors may result to varying degrees based on these dimensions. The cognitive dimension reflects the individual's cognizance of social categories and own self-categorization into one or more of them. Drawing on Harquail (1998) and Thoits (1989), Ashforth (2001) suggests the affective dimension of social identity is reflected in the strength of one's association with what may be seen as a cognitively appropriate in-group. The stronger the emotional arousal that is associated with a social group, the more important one's identity within that group is. Further, the positive or negative nature of group-related emotional arousal is an important component in the individual's evaluation of his social identity (Ashforth, 2001). The assignment of valence to one's in-group membership enhances both the individual's social identity and self-esteem. In the new world of work, patterns of association have become more sophisticated, spurring the need to reflect on the new mix of sources for emotional arousal. 
Katz and Kahn (1978) and Ashforth (2001) discuss competing identities, as individuals accept and perform roles in social interactions (Goffman, 1959). For example, one may be a parent, an employee, an activist, and a customer, portraying each of these roles in appropriate settings. These roles, together, make up the employee's role set (Katz \& Kahn, 1978; Ashforth, 2001), yet adding the layer of a gig worker role to the mix offers more dynamism and complexity to an understanding of the focal aspects used in the creation of a work identity.

In many cases, the identification with an in-group, and, consequently, a heightened sense of self-esteem, is achieved through the categorization of out-groups as inferior to the individual's primary in-group (Simon \& Brown, 2000). In the gig context, if one perceives that one works with a "better" company, then he feels better about himself and experiences a strengthened work identity. Because gig workers have negotiated exchanges concerning the work via a digital platform, where explicit agreements on the time and care dedicated to the worker and the organization are established in clear terms, gig workers are more likely to experience positive feelings when successful, and negative emotions like self-shaming when unsuccessful (Lawler, 2001). Thus, social identity is important to individuals, and it has substantial implications for organizations that strive to promote individual efforts toward their collective betterment, whether or not these individuals are conventional organizational employees (Karriker \& Hartman, 2018). Even though some 'serial' gig workers (i.e., with repeating gigs) may have short- and longer-term relationships with organizations or individuals, gig workers do not necessarily have a single, central organizational relationship. In keeping with He and Brown (2013), we assert the need to reevaluate the concept and implications of social identity in the context of the gig economy, in which this organizational and structural centrality are limited, or nonexistent, factors.

\section{GIG CONFIGURATION AND WORK IDENTITY}

Nontraditional workers comprise approximately 20 to 40 percent of the workforce in the U.S. and EU15 countries (McKinsey Global Institute; U.S. Government Accountability Office, 2015). Between onethird and one-half of U.S. gig workers relied on gig work for their primary income, and approximately 10 percent of the gig workforce were full-time gig workers ("How-many-gig-workers-are-there?" n.d.). Alongside Tajfel's invocation of knowledge and emotional significance in social identity work, attention to these configurations helps apply social identity theory to gig workers. Employees have long been identifying in some way with their work groups and organizations. What is different is the gig context in which a work identity emerges, causing it to manifest to greater prominence because the relationship with a primary organization is more transient, more transactional, and arguably less committed. Hameed, Roques, and Ali Arain (2013) distinguish the organizational identification process in terms of feelings of respect for, and from, an organization. We suggest these perceptions can be generated via negotiated exchanges (Lawler, 2001) with organizations and groups that may serve as organizational proxies. Further, we assert that organizational identification's counterpart in the gig economy is the [individual] work identity.

Gig work itself is not a new construct, with its origins in the work of musicians (i.e., "playing a gig"), and it encompasses various configurations of contract and independent work (Kirin, 2017). In order to highlight their distinctions and begin to clarify ways in which individuals' respective social identities may develop, we present two general work configurations: traditional employment and gig work (Table 1). 
TABLE 1

OVERVIEW OF TRADITIONAL AND GIG WORK CONFIGURATION

\begin{tabular}{|c|c|c|c|c|}
\hline & \multicolumn{2}{|c|}{ Traditional Employment } & \multicolumn{2}{|c|}{ Gig Work } \\
\hline & Full-Time & Contingent & Supplemental & Primary \\
\hline Example 1 & $\begin{array}{l}\text { Store Manager at } \\
\text { National Restaurant } \\
\text { Chain }\end{array}$ & $\begin{array}{l}\text { Store Manager } \\
\text { employed by a Retail } \\
\text { Placement Agency } \\
\text { works at a National } \\
\text { Restaurant Chain }\end{array}$ & $\begin{array}{l}\text { Store Manager at } \\
\text { National Restaurant } \\
\text { Chain who also } \\
\text { works as an Uber and } \\
\text { Uber Eats Driver }\end{array}$ & $\begin{array}{l}\text { Full-Time Uber and } \\
\text { Uber Eats Driver }\end{array}$ \\
\hline Example 2 & $\begin{array}{l}\text { Graphic Designer } \\
\text { for a Large } \\
\text { Automotive } \\
\text { Company }\end{array}$ & $\begin{array}{l}\text { Part-time or seasonal } \\
\text { Graphic Designer at } \\
\text { Large Automotive } \\
\text { Company }\end{array}$ & $\begin{array}{l}\text { Graphic Designer at } \\
\text { Large Automotive } \\
\text { Company who also } \\
\text { works as a freelance } \\
\text { Graphic Designer } \\
\text { bidding for jobs on } \\
\text { Upwork }\end{array}$ & $\begin{array}{l}\text { Full-Tine Freelance } \\
\text { Graphic Designer } \\
\text { bidding for jobs on } \\
\text { Upwork }\end{array}$ \\
\hline \multicolumn{5}{|l|}{ Work Characteristic } \\
\hline $\begin{array}{l}\text { Organizational or } \\
\text { Personal Holding } \\
\text { Environment* }\end{array}$ & Organizational & Organizational & Both/Personal & Personal \\
\hline $\begin{array}{l}\text { Financial Instability \& } \\
\text { Job Insecurity** }\end{array}$ & Lower & Lower & Moderate & High \\
\hline Autonomy** & Lower & Lower & Moderate & High \\
\hline $\begin{array}{l}\text { Career Path } \\
\text { Uncertainty** }\end{array}$ & Lower & Lower & Moderate & High \\
\hline Work Transience** & Lower & Moderate & Moderate & High \\
\hline $\begin{array}{l}\text { Physical and } \\
\text { Relational } \\
\text { Separation** }\end{array}$ & Lower & Lower & Moderate & High \\
\hline Employment Status & Direct Employment & $\begin{array}{c}\text { Direct Employment, } \\
\text { Alternative } \\
\text { Arrangements }\end{array}$ & Blended & $\begin{array}{l}\text { Digitally Contracted } \\
\text { (possibly multiple) }\end{array}$ \\
\hline $\begin{array}{l}\text { Receive Benefits like } \\
\text { Health Insurance from } \\
\text { Employer or } \\
\text { Contracted } \\
\text { Employment*** }\end{array}$ & Often & Occasionally & Occasionally & Rarely \\
\hline $\begin{array}{l}\text { Part of a pool of } \\
\text { workers who are only } \\
\text { called to work or } \\
\text { contracted to work as } \\
\text { needed*** }\end{array}$ & No & Sometimes & Sometimes & Frequently \\
\hline $\begin{array}{l}\text { Full-Time or Part- } \\
\text { Time }\end{array}$ & Either & Either & Either & Either \\
\hline Source of Income & Primary & Primary & Blended & Primary \\
\hline Social Relations & $\begin{array}{l}\text { Mostly Face-to- } \\
\text { Face }\end{array}$ & Mostly Face-to-Face & $\begin{array}{c}\text { Combination of } \\
\text { Mostly Face-to-Face } \\
\text { and Possibly Digital } \\
\text { Platform }\end{array}$ & Digital Platform \\
\hline
\end{tabular}

Note: *See Petriglieri, G., Ashford, S.J., \& Wrzesniewski, A. (2019). Agony and Ecstasy in the Gig Economy: Cultivating Holding Environments for Precarious and Personalized Work Identities. Administrative Science Quarterly, 64(1), 124-170.

** Ashford, S.J., Cazab, B.B., \& Reid, E.M. (2018). From surviving to thriving in the gig economy: A research agenda for individuals in the new world of work. Research in Organizational Behavior.

***https://www.bls.gov/news.release/pdf/conemp.pdf 
Gig work is transacted in a digital marketplace through companies that provide digital matching services that (1) facilitate peer-to-peer transactions using online platforms or mobile apps; (2) utilize userbased rating systems; (3) offer workers flexibility in determining their hours; and (4) place responsibility on workers to provide whatever tools or assets are necessary to accomplish their work (Smith, 2016). Work is assigned through digital platforms serving as intermediaries between a knowledge worker, such as a graphic designer bidding on work, and a prospective client. While the work does not occur on the digital platform, the social relations between the gig worker and the clients do. Relationship success is ranked on the worker's profile by a client in the form of stars or client satisfaction metrics, which are later used by clients in determining whom to hire, and higher ratings influence a worker's future employability (Gandini, 2019).

Gig workers may have low - or nonexistent - levels of organizational attachment, which may be only technological (Ashford, et al., 2018). For them, independent work, or [collection of] gigs, is just a source of income (McKinsey Global Institute, 2016). In supplemental gig configurations, one may perform work with multiple organizational referents as an employee or temporary employee with "side hustles"; that is, gigs are supplementary or complementary income. Rockmann and Ballinger (2017) investigate the relationships between on-demand workers and the third-party firms that facilitate their short-term service contracts with clients. Essentially, these firms broker the 'gigs,' or the work assignments. Based on selfdetermination theory's framework, intrinsically motivated on-demand workers may develop organizational identification with on-demand firms based on aspects of the work itself, as opposed to mere economic satisfaction. In this case, the social identity is formed with the third-party firm as referent as it orchestrates arrangements that meet the individual's innate psychological needs (Jabagi et al., 2019) and membership in an in-group. The benefits of this organizational identification to the individual are feelings of competence, connectivity, and autonomy; to the firm, they may include economic benefits associated with such loyalty. Extending this work, we infer that a gig worker also develops a relationship with each client under certain conditions and that these interactions will become a network of negotiated exchanges forming a source of work identity.

Whether the gig work configuration is supplemental or primary, the individual's connection(s) to the contracting organization(s) is precarious as this organization only has to be deactivated from the matching platform to separate itself from the gig worker. Thus, uncertainty and insecurity are the prices for gig work flexibility. We anticipate that because organizational identification insulates one against those anxieties in traditional arrangements, the gig worker's work identity will serve a similar function. We assert these emerging gig economy configurations present ample opportunities for widely varying work-related interactions and support the development of individual work identities. In this context, we expect that individuals in every employment category develop images of their affiliates and themselves and arrive at work identities. However, we have found no scholarly examination of these cognitive and affective connections with employment configuration as a factor in the development of the work identity.

\section{AFFECTIVE EVENTS THEORY}

Ashforth (2001) holds that one's cognitions and affects toward a given role determine one's behaviors in the portrayal of that role and, further, that these cognitions and affects are largely determined by the events that comprise organizational life. Weiss and Cropanzano (1996) frame Affective Events Theory (AET) in an exploration of stable patterns and change-precipitating events. These events are called affective events and they can vary substantially from one worker to another. We assert the heightened importance of reflection on the availability and influence of affective events in the complex patterns of the gig economy.

Affective Events Theory focuses on the structure, causes, and consequences of affective experiences at work. We understand such events in the form of a physical or virtual pat on the back, a bonus, or an award received at a company dinner or emphasized on social media (Weiss \& Cropanzano, 1996), and we assert that certain work configurations may make these affective events more or less likely as we question the potential patterns of affective events available to gig workers. 


\section{AET Structural Dimensions: Physical, Temporal, and Administrative}

Ashford and colleagues (2018) list several structural dimensions for independent work: physical, temporal, and administrative attachment to companies (Ashford, et al., 2007). Like traditional employees, gig workers regularly experience social exchanges that may be characterized as affective, but the psychological effects of more tenuous organizational connections will increase the extent to which these positive or negative exchanges impact gig workers' identities.

Following Ashforth (2001), we suggest that an individual interprets events through objective cues that instruct him about appropriate role behaviors, as well as through his emotional arousal connected with those events. So, the degree to which he understands, accepts, and performs a given role, or an identity, is predicted by the existence and strength of cognitive and affective reinforcers embedded within work events. Because one can understand and portray a role through the interpretation of cognitive cues (Ashforth, 2001), the identification with that role must be largely a factor of the affective evaluation of it. The strength of identification with an organizational role or role set, then, is predicated on the experience of affective events. These affective events may be experienced differently by permanent and gig workers as dictated by features of their respective work environments including physical, temporal, and administrative dimensions (Ashford et al., 2018; Ashford, et al., 2001) which provide a frame for this exploration of the impacts of gig work configurations. Figure 1 presents the currently proposed gig work identity model.

FIGURE 1

\section{GIG WORK IDENTITY MODEL}

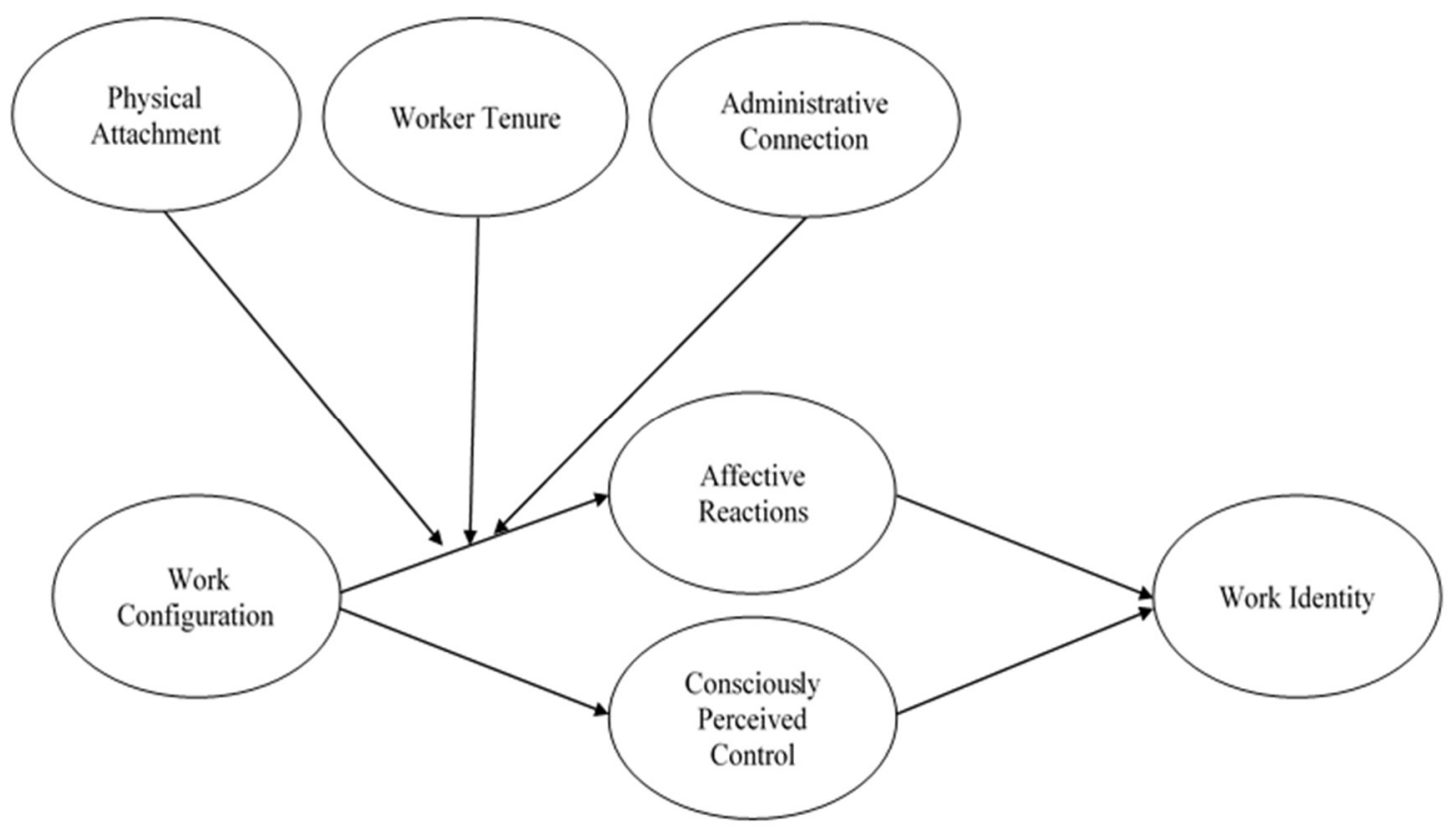

\section{Physical Dimension}

Conventional arrangements rely on personal bonds and face-to-face communications to develop an individual's identification with a work group (Brewer \& Gardner, 1996). Proximity and the uniformity of experience serve as the basis for identification with workgroup members. However, the work, team, and organizational identification in virtual settings suggest the foundational aspects of organizational identification research may be altered as work arrangements evolve. Fiol and O'Connor (2005) proposed a conceptual model for the development of team identification in hybrid and virtual teams, and empirical data suggests having all members isolated is more beneficial for identification (O'Leary \& Mortensen, 2010). Employee control over office space management or compensation systems is also positively related to organizational identification (Hunt, 2012; Knight \& Haslam, 2010), but it is unclear if these results extend 
to virtual or gig workers. Bartel, Wrzesniewski, and Wiesenfeld (2012) found that physical isolation negatively predicts organizational identification among virtual workers, and specifically, those workers who perceived they were not respected were most deeply impacted. On a practical, daily basis, many workers in gig arrangements labor together with traditionally employed full- and part-time workers. They are integrated as members of working groups and teams, and members or affiliates of the same work organizations. The dimension of physical attachment to work is nuanced in the era of technological advancement that has helped spearhead the gig economy, yet it likely impacts the emotional responses experienced by gig workers in various work configurations.

\section{P1: Physical attachment to an organization moderates the relationship between work configuration and affective reactions.}

\section{Temporal Dimension}

We suggest an employee's history with affective events can also contribute to her strength of organizational identification. Related to the temporal dimension, the expectation is that gig workers do derive and display organizational identification in the same ways that permanent workers do: through affect, behavior, and cognition; yet their tenure with these patterns impacts their reactions to them. For example, a serial gig worker, one with repeating gigs and who forges an ongoing client relationship, may react differently to affective events and control perceptions that would a gig worker without such a length of association. Ashforth (2001) also refers to "transition dynamics" as the degree to which individuals exit roles and enter new roles. Here, the individual's career is seen as a series of role acceptances, portrayals, and transitions into new roles, or new work identities, consistent with the idea that gig workers and permanent workers both react to affective events and derive identities from them with regard to the actual time spent affiliated with a given entity.

\section{P2: Gig worker tenure with clients moderates the relationship between work configuration and affective} reactions.

\section{Administrative Dimension}

Virtual, contract, part-time, temporary, and traditional workers work together in teams daily, and any distinctions among employment statuses are largely underlying ones. The legal employment contract exists only in the background of everyday work life. However, because of the psychological effects of a more tenuous employment status inherent in differences in underlying structures provided by the contractual relationship - the administrative dimension, the expectation is that gig workers do not identify as strongly with their affiliate organizations as directly employed permanent workers do, and that this identification may be heightened or attenuated by reactions to meaningful and potentially very different events. Even though conventional employees experience positive emotions and high job satisfaction in autonomous and less structured arrangements (Wegge et al., 2006), the gig setting is much more amorphous and may not offer opportunities to structure programs to onboard and engage workers. Gig workers may work in proximity to permanent employees, providing an opportunity to make comparisons about the experiences received at work for them relative to those experiences available to their permanent peers. As a result, gig workers can get a sense that they are located on the periphery of the organization, and we expect they will experience a transactional type of organizational membership and an organizational identification level commensurate with this form of membership. As such, administrative connections requiring frequent communications and social ties between workers at the organization have more depth. While impersonal communications among a diffused or shifting group of workers would have less organizational depth.

\section{P3: The depth of the administrative connection moderates the relationship between work configuration and affective reactions.}




\section{Affective Reactions and Work Identity}

At the primary gig extreme depicted in Table 1, the gig worker's holding environments (Petriglieri, et al., 2019) serve as the structures for their development of work identities. In the 'middle,' supplemental gig workers may also have the need for such holding environments to support their work identities. Gig workers' work identities may encompass multiple organizational and gig identifications, perhaps related to their own created networks. Client satisfaction metrics, in the form of stars or client satisfaction metrics and client reviews posted on the digital platform, impact the formalization of the worker's identity. Platform operators also send emails to gig workers when ratings fall below designated standards and highlight specific ratings that lead to poorer overall ratings for the worker. Suggestions on how to improve future performance and ratings are also provided by the digital platform operator as a way to help the workers meet advertised work quality expectations (Kirin, 2017). Affect and performance patterns over time suggest that work dimensions have an indirect effect on affective reactions, because they make affective work events more or less likely, thus influencing affective reactions. This supports our assertion that affective reactions may serve as the intervening mechanisms in the development of work identities in the gig economy. Employees in traditional work arrangements appear to follow a predictable trajectory consistent with a socialization taxonomy that includes newcomers' experiencing events associated with socialization as employees commonly perceived themselves as either learning to love (strengthening of identification) or experiencing a honeymoon hangover (weakening of identification) state (Solinger, Van Olffen, Roe, \& Hofmans, 2013).

Weiss and Cropanzano (1996) propose that patterns of affective reactions influence both overall feelings about one's job and discrete behaviors at work. Affective work events elicit affective reactions, mediated, or at least moderated by the general disposition of the individual. The pattern of affective reactions results in specific, affect-driven behaviors, as well as work attitudes, which themselves are related to judgment-driven behaviors. Given the importance of emotions in the work setting, the assertion here is that emotions and rationality are, indeed, intertwined and inseparable. Indeed, in the new world of work, gig workers are often pursuing their 'passions' as freelancers to varying degrees, further emphasizing the potential impact of emotional arousal regarding affective events on their affiliations with organizations and working groups. Self-determination theory's power of intrinsic motivation (Gagne \& Deci, 2005) has been touted as offering gig workers the chance to find fulfillment through flexibility, convenience, and the validation of expertise, among other stimulations, derived from autonomous work (Jabagi et al., 2019; McKinsey Global Institute, 2016; Petriglieri, Ashford, \& Wrzesniewski, 2019; Rockmann \& Ballinger, 2017).

\section{P4: Work configuration impacts work identity through the influence of affective reactions.}

\section{Sense of Agency and Work Identity}

Weiss and Cropanzano (1996) make clear the fundamental entwinement of emotions and cognitions in the work environment. Managers may offer supportive work experiences by acknowledging employees' perspectives and asking for their viewpoints; offering options as to how they might do aspects of their jobs; empowering decision making; and providing positive feedback (Humphrey et al., 2007; Van den Broeck et al., 2010). However, not all gig workers desire affective experiences in the traditional work settings of human interactions. We propose that gig workers, in particular, do not miss the comradery and emotional connections found in the conventional employee-employer relationship as they are often replaced with connections to other significant people (Petriglieri, Ashford, \& Wrzesniewski, 2019) and potentially by social networks (Jabagi et al. 2019). This perception is evidenced by the gig configuration that, by definition, is supported through digital platforms with little or no direct interpersonal contact. Here, essentially, the social environment is digital. Because financially secure full-time gig workers may not need or seek identification with the organizations with whom they contract, they may not find salient the affective events from which they are excluded but that are normally experienced by traditional full-time employees. Nonetheless, these workers do develop work identities, perhaps derived from a broader community of gig 
contractors, or from their profession (e.g., software writers) or other cognitive connections of importance to them.

Thus, in this effort to explore how a gig worker develops a work identity, it is important to consider influences beyond affect. One such potential influence is Sense of Agency (SoA), which may be both motivation and reward for gig work. Synofzik et al. (2013) discuss Sense of Agency (SoA) as "the registration that I am the initiator of my actions" (p. 1). McKinsey Global Institute (2016) sought to determine characteristics of workers outside the conventional worker arrangement, including work that features a high degree of autonomy, payment by task assignment, and a short-term relationship between the worker and clients, and suggested they could be subdivided into four categories: a) "free agents" who prefer and obtain primary income from independent work; b) "casual earners" who prefer independent work to supplement their income; c) those working in independent work out of necessity to earn their primary income ("reluctants"); or d) those working independently out of necessity to earn supplemental income ("financially strapped"). Gig workers out of need, rather than choice, might have a lower sense of agency with regard to work than would their counterparts who are working independently of their own volition, which Tapal, Oren, Dar, and Eitem (2017) depict as "consciously perceived control" (p. 1). This distinction cross-sects primary and supplementary work arrangements to suggest a greater sense of agency willing gig workers might have relative to those who do gig out of necessity. Nonetheless, freelance workers in general have more control over their work schedules, and ultimately their careers, due to the independent nature of their work.

This sense of agency (Tapal et al 2017, p. 1) impacts one's work identity. For example, it may result in a work identity related to the chosen work (e.g., an artist, a graphic designer, etc.). Conversely, a person desiring a job as full-time nurse with a permanent working arrangement may, in the absence of such an opportunity, must take a job temporarily as a travel nurse. NurseFly, a healthcare staffing platform and digital marketplace, connects nurses to open jobs when nurses are struggling to find career opportunities (Altschuler, 2020). Such reluctants with an aversion to travel may not feel a connection with their professional community. They may be unable to develop an organizational identity as they operate outside the conventional employee work arrangement. Perhaps, the individual's work identity will become negative (e.g., "gun-for-hire, not good enough for full-time work, just in it for the money, no point in being loyal to the hospital," etc.). If this arrangement were followed by unwanted gaps in work assignments during slack times (e.g., layoffs due to financial struggles or economic shutdowns, etc.), the reluctant could have a potentially weaker work identity and would yearn for an employment relationship where she would be able to identify and feel validated professionally with the preferred full-time employer. Casual earners and financially strapped gig workers (i.e., part-time contractors, side-hustle workers, etc.), comprise $56 \%$ of independent workers according to McKinsey Global Institute (2016); they may not seek identity from the contracting firm, but instead focus strictly on the exchange relationship for their work identities. However, such relationships could be particularly nuanced as those working full-time could participate in identitybuilding activities in their traditional work arrangements and be able to make comparisons about what is present and absent during their side-hustle work.

Gig workers form conscious perceptions of control - a sense of agency - based mainly on the influence of work configuration and the impetus for those configurations. In turn, one's sense of agency impacts his or her work identity. Here, we see a need to explore the potential mediating role of this cognitive aspect of individual agency, consciously perceived control, and its relationship with affective reactions in the work configuration - work identity relationship.

\section{P5: Work configuration impacts work identity through the influence of consciously perceived control.}

\section{CONCLUSION}

There are virtually no studies that strive to understand how a work identity dynamically develops over time, or even if it does develop or develops differently for workers with various nontraditional work configurations. In this effort, we call for an investigation of the influences of work configuration, affective 
reactions, and control cognitions in the work identification process experienced by gig workers (see also Marique \& Stinglhamber, 2011). Extant literature has provided provocative findings with potential implications for diverse groups of workers. Perhaps most important is the relationship between levels of conventional organizational identification and outcome variables, such as creativity (Brammer, He, \& Mellahi, 2015), job performance (Kaufman, 1960) and intention to remain for traditional workers (WanHuggins et al, 1998). This positive impact on individual and organizational performance is achieved, among other ways, through the retention of productive workers and through higher quantity and quality work borne from met psychological needs; in the gig economy, similar favorable outcomes may accrue from strong work identities.

Even though organizational identification is such a powerful and important construct traditionally, we note that related antecedents and consequences have been understudied in the context of the growing gig economy. Along with the development of novel work arrangements, theories of how gig workers are integrated into work processes, employment, and rewards are also needed. For instance, the recruitment and repeating engagement of gig workers may have consequences on the quality of the services provided, as these workers may have been excluded from training, on-boarding and socialization, career planning, and the performance management processes available to the permanent employees they work alongside or have replaced. Similarly, compensation and benefits provided for gig workers could be viewed very differently from the compensation and benefits traditionally offered by the organization to their permanent colleagues. Flexible employment in the case of independent contractors and temporary workers may be associated with lower work satisfaction (Wilkin, 2013); yet not much is known about the work identity a gig worker derives from job flexibility. Wilkin (2013) found the satisfaction of temporary workers improved when human recourses offered them benefits similar to those offered to traditional employees, but how much benefit similarity impacts gig worker identity remains unknown. Future research may shed light in this arena. Further, in the relative absence of organizations as singular structural referents, gig workers will still seek fulfillment of psychological needs via the development of individual work identities. The current effort contributes to social identity theory as it begins to address the affective and cognitive mechanisms through which individuals in gig work configurations construct the work identities that enhance their self-esteem and insulate them from social anxieties.

People react to the events of their work lives; these reactions drive their immediate affective states, and these states can vary over time. Some events are positive, some are negative, and the emotional reactions to these events cause certain work behaviors. The physical, temporal, and administrative connections with an organization and its proxies interact with work configuration to influence the affective reactions that impact individual work identities. Work configurations are also related to cognition of control, which impacts work identity differentially based on the motivation for gig participation. Future research should explore the implications for work identities based on work configurations in both general terms and regarding the broad array of specific work arrangements as they apply to generational demographics (Karriker \& Hartman, 2018). For example, does a Millennial gig worker experience the same affective reactions to digital exchanges like 5-star customer ratings that she does to personal interactions like workplace celebrations? And does this same preference hold for members of Generation Z, Baby Boomers, and/or Gen Xers? What, if any, are the generational differences in preferences for the digital platform component of gig work, and how do they impact affective reactions and sense of agency? The expanding gig economy provides a challenging and dynamic setting for researchers to explore these and other impactful phenomena in this new world of work. 


\section{REFERENCES}

Agarwal, D., Bersin, J., Lahiri, G., Schwartz, J., \& Volini, E. (2018). Introduction: The rise of the social enterprise. 2018 Global Human Capital Trends. Deloitte Human Capital Consulting. Retrieved from https://www2.deloitte.com/insights/us/en/focus/human-capitaltrends/2018/introduction.html

Altschuler, W. (2020). What it's like to be a travel nurse during a pandemic. Forbes [online]. Retrieved July 18, 2020, from https://www.forbes.com/sites/wendyaltschuler/2020/06/23/what-its-like-tobe-a-travel-nurse-during-a-pandemic/\#1907cb8e115b

Ashford, S.J., Caza, B.B., \& Reid, E.M. (2018). From surviving to thriving in the gig economy: A research agenda for individuals in the new world of work. Research in Organizational Behavior, 38, 23-41. https://doi.org/10.1016/j.riob.2018.11.001

Ashforth, B.E., Harrison, S.H., \& Corley, K.G. (2008). Identification in organizations: An examination of four fundamental questions. Journal of Management, 34, 325-374.

https://doi.org/10.1177\%2F0149206308316059

Ashforth, B.E. (2001). Role Transitions in Organizational Life: An Identity-Based Perspective. Mahwah, NJ: Lawrence Erlbaum Associates. https://10.5465/amr.2001.5393915

Banks, C. (2019). Health, safety, well-being and economic security implications of gig work: An interdisciplinary perspective. International Labour Organization. Retrieved from https://www.ilo.org/global/topics/safety-and-health-at-work/events-training/eventsmeetings/world-day-for-safety/33thinkpieces/WCMS_674004/lang--en/index.htm

Barley, S.R. \& Kunda, G. (2006). Contracting: A new form of professional practice. Academy of Management Perspectives, 20(1) 45-66. https://doi.org/10.5465/amp.2006.19873409

Barley, S.R. Bechky, B.A., \& Milliken, F.J. (2017). The changing nature of work: Careers, Identities, and work lives in the $21^{\text {st }}$ century. Academy of Management Discoveries, 3(2), 111-115. https://doi.org/10.5465/amd.2017.0034

Bartel, C.A. (2001). Social comparisons in boundary-spanning work: effects of community outreach on members' organizational identity and identification. Administrative Science Quarterly, 46(3), 379-413. https://doi.org/10.2307/3094869

Bartel, C.A., Wrzesniewski, A., \& Wiesenfeld, B.M. (2012). Knowing where you stand: Physical isolation, perceived respect, and organizational identification among virtual employees. Organization Science, 23(3), 743-757. https://www.jstor.org/stable/23252086

Bernhardt, A. (2014). Labor Standards and the Reorganization of Work: Gaps in Data and Research. IRLE working paper no. 100-14. Berkeley: University of California, Institute for Research on Labor and Employment. Retrieved June 25, 2019, from https://irle.berkeley.edu/files/2014/LaborStandards-and-the-Reorganization-of-Work.pdf

Brammer, S., He, H., \& Mellahi, K. (2015). Corporate Social Responsibility, Employee Organizational Identification, and Creative Effort: The Moderating Impact of Corporate Ability. Group \& Organization Management, 40(3), 323-352. https://doi.org/10.1177/1059601114562246

Brewer, M.B., \& Gardner, W. (1996). Who is this "we"? Levels of collective identity and self representations. Journal of Personality and Social Psychology, 71(1), 83-93. https://doi.org/10.1037/0022-3514.71.1.83

Cappelli, P., \& Keller, J.R. (2014). Talent Management: Conceptual Approaches and Practical Challenges. Annual Review of Organizational Psychology and Organizational Behavior, 1, 305331. https://doi.org/10.1146/annurev-orgpsych-031413-091314

DeSanctis, G., \& Poole, M.S. (1997). Transitions in teamwork in new organizational forms. Advances in Group Processes, 14(1), 157-176. https://doi.org/10.1177/104649602237167

Dutton, J.E., \& Dukerich, J.M. (1991). Keeping an eye on the mirror: Image and identity in organizational adaptation. Academy of Management Journal, 34(3), 517-554. https://doi.org/10.2307/256405

Dutton, J.E., Dukerich, J.M., \& Harquail, C.V. (1994). Organizational images and member identification. Administrative Science Quarterly, 39(2), 239-263. https://doi.org/10.2307/2393235

156 Journal of Organizational Psychology Vol. 21(2) 2021 
EY. (2016). Global Contingent Workforce Study. Retrieved from https://gigeconomy.ey.com/

Fiol, C.M., \& O'Connor, E.J. (2005). Identification in face-to-face, hybrid, and pure virtual teams: Untangling the contradictions. Organization Science, 16(1), 19-32. https://doi.org/10.1287/orsc. 1040.0101

Gagne, M., \& Deci, E.L. (2005). Self-determination theory and work motivation. Journal of Organizational Behavior, 26(4), 331-362. https://doi.org/10.1002/job.322

Gandini, A. (2019). Labour process theory and the gig economy. Human Relations, 72(6), 1039-1056. https://doi.org/10.1177/0018726718790002

Goffman, E. (1959). The Presentation of Self in Everyday Life. Garden City, NJ: Doubleday. https://10.4236/aasoci.2015.52007

Grandey, A.A., Tam, A.P., \& Brauburger, A.L. (2002). Affective states and traits in the workplace: Diary and survey data from young workers. Motivation and Emotion, 26(1), 31-55. https://doi.org/10.1023/A:1015142124306

Hameed, I., Roques, O., \& Ali Arain, G. (2013). Nonlinear Moderating Effect of Tenure on Organizational Identification (OID) and the Subsequent Role of OID in Fostering Readiness for Change. Group \& Organization Management, 38(1), 101-127. https://doi.org/10.1177/1059601112472727

Harquail, C.V. (1998). Organizational identification and the "whole person": Integrating affect, behavior, and cognition. In D.A. Whetten \& P.C. Godfrey (Eds.), Identity in Organizations: Building Theory Through Conversations (pp. 223-231). Thousand Oaks, CA: Sage.

He, H., \& Brown, A.D. (2013). Organizational Identity and Organizational Identification: A Review of the Literature and Suggestions for Future Research. Group \& Organization Management, 38(1), 3-35. https://doi.org/10.1177/1059601112473815

How many gig workers are there? (n.d.). Retrieved October 25, 2019, from https://www.gigeconomydata.org/basics/how-many-gig-workers-are-there

Humphrey, S.E., Nahrgang, J.D., \& Morgeson, F.P. (2007). Integrating motivational, social, and contextual work design features: A meta-analytic summary and theoretical extension of the work design literature. Journal of Applied Psychology, 92, 1332-1356. https://10.1037/00219010.92 .5 .1332

Hunt, C.S. (2012). The emerging influence of compensation plan choice on salesperson organizational identification and perceived organizational support. Journal of Leadership, Accountability and Ethics, 9(1), 71-80. Retrieved from https://search.proquest.com/docview/1019050890?accountid=10639

Jabagi, N., Croteau, A.M., Audebrand, L.K., \& Marsan, J. (2019). Gig-workers' motivation: thinking beyond carrots and sticks. Journal of Managerial Psychology, 34(4), 192-213. https://doi.org/10.1108/jmp-06-2018-0255

Judge T.A., Hulin C.L., \& Dalal, R.S. (2011). Job satisfaction and job affect. In S.W.J. Kozlowski (Ed.), The Oxford Handbook of Industrial and Organizational Psychology. Oxford University Press, New York. Retrieved from https://10.1093/oxfordhb/9780199928309.013.0015

Karriker, J.H., \& Hartman, N.S. (2018). Social media and dynamic capabilities: Mining Millennial resources. Journal of Organizational Psychology, 18(4), 43-57. https://doi.org/10.33423/jop.v18i4.84

Katz, D., \& Kahn, R.L. (1978). The Social Psychology of Organizations (2nd ed.). New York: Wiley. https://10.1007/978-3-319-31816-5_3059-1

Kaufman, H. (1960). The Forest Ranger. Baltimore, MD: Johns Hopkins. https://10.1111/j.1540$6210.2012 .02591 . x$

Kirin, J. (2017). A third way for applying US labor laws to the online gig economy: Using the franchise business model to regulate gig workers. Journal of Business \& Technology Law, 12(2), 193-226. Retrieved from http://digitalcommons.law.umaryland.edu/jbtl/vol12/iss $2 / 4$

Knight, C., \& Haslam, S.A. (2010). The relative merits of lean, enriched, and empowered offices: An experimental examination of the impact of workspace management strategies on well-being and 
productivity. Journal of Experimental Psychology: Applied, 16(2), 158-172.

https://10.1037/a0019292

Lawler, E.J. (2001). An affect theory of social exchange. American Journal of Sociology, 107(2), 321352. https://digitalcommons.ilr.cornell.edu/articles/652/

Mael, F. (1988). Organizational identification: construct redefinition and a field application with organizational alumni. Unpublished doctoral dissertation, Wayne State University, Detroit, MI. https://doi.org/10.1177/0013164492052004002

Mael, F., \& Ashforth, B.E. (1992). Alumni and their alma mater: A partial test of the reformulated model of organizational identification. Journal of Organizational Behavior, 13(2), 103-123.

https://psycnet.apa.org/doi/10.1002/job.4030130202

Marique, G., \& Stinglhamber, F. (2011). Identification to proximal targets and affective organizational commitment: The mediating role of organizational identification. Journal of Personnel Psychology, 10(3), 107-117. Retrieved from

https://www.researchgate.net/deref/http\%3A\%2F\%2Fdx.doi.org\%2F10.1027\%2F1866$5888 \% 2 \mathrm{Fa} 000040$

McKinsey Global Institute. (2016). Independent work: Choice, necessity, and the gig economy. Retrieved from

https://www.mckinsey.com/ /media/McKinsey/Featured\%20Insights/Employment\%20and\%20G rowth/Independent $\% 20$ work $\% 20$ Choice $\% 20$ necessity $\% 20$ and $\% 20$ the $\% 20$ gig\%20economy/Indep endent-Work-Choice-necessity-and-the-gig-economy-Executive-Summary.ashx

O'Leary, M.B., \& Mortensen, M. (2010). Go (con)figure: Subgroups, imbalance, and isolates in geographically dispersed teams. Organization Science, 21(1), 115-131. https://10.1287/orsc. 1090.0434

Petriglieri, G., Ashford, S.J., \& Wrzesniewski, A. (2019). Agony and ecstasy in the gig economy: Cultivating holding environments for precarious and personalized work identities. Administrative Science Quarterly, 64(1), 124-170. https://doi.org/10.1177\%2F0001839218759646

Rockmann, K.W., \& Ballinger, G.A. (2017). Intrinsic motivation and organizational identification among on-demand workers. Journal of Applied Psychology, 102(9), 1305-1316. https://psycnet.apa.org/doi/10.1037/ap10000224

Simon, B., \& Brown, R. (2000). Perceived intragroup homogeneity in minority-majority contexts. In C. Stangor (Ed.), Stereotypes and Prejudice: Essential Readings. Philadelphia: Psychology Press.

Smith, A. (2016). Gig work, online selling and home sharing. Pew Research Center, 17. Retrieved from https://www.pewresearch.org/internet/2016/11/17/gig-work-online-selling-and-home-sharing/

Solinger, O.N., Van Olffen, W., Roe, R.A., \& Hofmans, J. (2013). On becoming (un) committed: A taxonomy and test of newcomer onboarding scenarios. Organization Science, 24(6), 1640-1661. https:// https://doi.org/10.1287/orsc.1120.0818

Synofzik, M., Vosgerau, G., \& Voss, M. (2013). The experience of agency: An interplay between prediction and postdiction. Frontiers in Psychology, 4, 127. https://doi.org/10.3389/fpsyg.2013.00127

Tajfel, H. (1978). Differentiation between social groups. London: Published in cooperation with European Association of Experimental Social Psychology by Academic Press.

Tapal, A., Oren, E., Dar, R., \& Eitam, B. (2017). The sense of agency scale: A measure of consciously perceived control over one's mind, body, and the immediate environment. Frontiers of Psychology, 8, 1552. https://10.3389/fpsyg.2017.01552

Thoits, P.A. (1989). The sociology of emotions. In W.R. Scott \& J. Blake (Eds.), Annual review of Sociology, 15, 317-342. Annual Reviews, Palo Alto, CA. https://doi.org/10.1146/annurev.so.15.080189.001533

U.S. Government Accountability Office. (2015). Contingent Workforce. Washington, DC: U.S. government Printing Office. Retrieved from https://www.gao.gov/assets/670/669766.pdf

Van den Broeck, A., Vansteenkiste, M., De Witte, H., Soenens, B., \& Lens, W. (2010). Capturing autonomy, competence, and relatedness at work: Construction and initial validation of the work- 
related basic need satisfaction scale. Journal of Occupational and Organizational Psychology, 83, 981-1002. https://10.1348/096317909X481382

Wan-Huggins, V.N., Riordan, C., \& Griffeth, R.W. (1998). The development and longitudinal test of a model of organizational identification. Journal of Applied Social Psychology, 28, 724-749. http://dx.doi.org/10.1111/j.1559-1816.1998.tb01728.x

Wegge, J., Dick, R.V., Fisher, G.K., West, M.A., \& Dawson, J.F. (2006). A Test of Basic Assumptions of Affective Events Theory (AET) in Call Centre Work 1. British Journal of Management, 17(3), 237-254. https://doi.org/10.1111/j.1467-8551.2006.00489.x

Weiss, H.M., \& Cropanzano, R. (1996). Affective events theory: A theoretical discussion of the structure, causes and consequences of affective experiences at work. Research in Organizational Behavior, 18, 1-74. Retrieved from https://www.scopus.com/record/display.uri?eid=2-s2.084975684491\&origin=inward\&txGid=84ac111 e81bcd941 f968cdff6ca81212

Wiesenfeld, B.M., Raghuram, S., \& Garud, R. (2001). Organizational identification among virtual workers: The role of need for affiliation and perceived work-based social support. Journal of Management, 27(2), 213-229. https://doi.org/10.1177\%2F014920630102700205

Wilkin, C.L. (2013). I can't get no job satisfaction: Meta-analysis comparing permanent and contingent workers. Journal of Organizational Behavior, 34(1), 47-64. https://doi.org/10.1002/job.1790 